\title{
TINGKAT KEBERHASILAN IMPLEMENTASI ENTERPRISE RESOURCES PLANNING DI BUMN SEKTOR MANUFAKTUR DI INDONESIA
}

\author{
Bachtiar H. Simamora; Kuspuji C.B. Wicaksono; Harly Toindo; Rudi
}

School of Business Management, BINUS University

Jln. K.H. Syahdan No. 9, Palmerah, Jakarta Barat 11480

bsim@binus.ac.id; kuspuji2910@binus.ac.id; harly@binus.ac.id;

\begin{abstract}
Implementation of the Enterprise Resource Planning (ERP) is an investment that does not appear in an organization. Indonesia State-Owned Enterprise, in particular manufacturing sector that have the leeway and autonomy to do ERP investments in supporting the achievement of its vision and mission. The World Economic Forum, put Indonesia on a ranking of 82 among the countries in the world in ICT utilization. This research aimed to test how big the investment that has been implanted in the area of information technology in the manufacturing sector, State-Owned Enterprises and the extent of the investment for the competitiveness of the company as well as its contribution to the wind of change on the manufactures business in Indonesia. This research was conducted to explore the performance of ERP implementation project. ERP implementation success rates seen from aspect of project management, determination of critical elements of urgency and contextual factors. The result is that all independent variables influence significantly to the success of the implementation of ERP of SOE's manufactures. The greatest contribution to the success of such in sequence is an element of urgency determination of critical factors, a contextual factors, and management of the project.
\end{abstract}

Keywords: Enterprise Resource Planning (ERP), ERP performance, critical element (CE)

\begin{abstract}
ABSTRAK
Implementasi Enterprise Resource Planning (ERP) adalah investasi tidak tampak dalam suatu organisasi. BUMN Indonesia secara khusus sektor manufaktur yang mempunyai keleluasaan dan otonomi untuk melakukan investasi ERP dalam mendukung pencapaian visi misinya. World Economic Forum, menempatkan Indonesia pada ranking 82 di antara negara-negara di dunia dalam pemanfatan ICT. Riset ini ditujukan untuk menguji seberapa besar investasi yang telah ditanamkan dalam bidang Teknologi Informasi pada BUMN sektor manufaktur, dan sejauh mana investasi tersebut berdaya guna bagi daya saing perusahaan maupun kontribusinya bagi roda perubahan pada bisnis manufaktur di Indonesia. Riset ini dilakukan untuk mengeksplorasi kinerja proyek implementasi ERP. Tingkat keberhasilan implementasi ERP dilihat dari aspek pengelolaan proyek, penentuan urgensi elemen kritis dan faktor kontekstual. Hasilnya bahwa semua variable independent berpengaruh secara signifikan terhadap keberhasilan implementasi ERP di sektor manufaktur BUMN. Yang paling besar kontribusi terhadap keberhasilan tersebut secara berurutan adalah, faktor penentuan urgensi elemen kritis, faktor kontekstual, dan pengelolaan proyek.
\end{abstract}

Kata kunci: Enterprise Resource Planning (ERP), kinerja ERP, critical element (CE) 


\section{PENDAHULUAN}

Perubahan ekonomi dan teknologi dan terutama perkembangan teknologi informasi secara signifikan telah mengubah lingkungan kerja dan manajemen usaha. BUMN, sebagai pilar utama perekonomian nasional, memiliki peran penting karena BUMN bertugas memberikan sumbangan bagi perkembangan perekonomian nasional pada umumnya dan penerimaan Negara pada khususnya (Republik Indonesia, 2003). Hal ini patut disadari mengingat dari sisi total aktiva seluruh BUMN pada tahun 2011 setara dengan Rp 2.962.699 Miliar, Capital Expenditur sebesar Rp 142,327 triliun dan operation expense Rp 1.226.551 Miliar (Kementerian BUMN, 2012a). Pada tahun yang sama, total APBN Indonesia setara dengan Rp 1.311,4 triliun, alokasi belanja modal dalam APBN 2011 mencapai Rp121,9 triliun atau 1,7 persen terhadap PDB (Departemen Keuangan, 2010). Dengan membandingkan kedua data tersebut, maka nilai CAPEX BUMN lebih besar dibandingkan rencana belanja APBN. Hal ini menunjukkan peran investasi BUMN menjadi sangat strategis dan penting untuk diperhatikan.

Memandang lebih jauh tentang BUMN, lembaga yang bertanggung jawab secara langsung untuk memonitor dan menggerakkan roda BUMN terletak pada Kementerian BUMN. Dengan demikian arah dan strategi Kementerian ini cukup penting untuk diamati. Dalam rencana strategis BUMN (Kementerian BUMN, 2012b), disebutkan beberapa tujuan BUMN adalah (Kementerian BUMN, 2012): (1) Memberikan sumbangan bagi perkembangan perekonomian nasional pada umumnya dan penerimaan negara pada khususnya. (2) Mengejar keuntungan. (3) Menyelenggarakan kemanfaatan umum berupa penyediaan barang dan/atau jasa yang bermutu tinggi dan memadai bagi pemenuhan hajat hidup orang banyak. (4) Menjadi perintis kegiatan-kegiatan usaha yang belum dapat dilaksanakan oleh sektor swasta dan Koperasi. (5) Turut aktif memberikan bimbingan dan bantuan kepada pengusaha golongan ekonomi lemah, koperasi, dan masyarakat.

Dari dasar tersebut, langkah Kementerian BUMN yang menancapkan visi institusi "Menjadi Pembina BUMN yang Profesional untuk meningkatkan nilai BUMN" patut diapresiasi. Lebih jauh, Kementerian BUMN juga telah merumuskan misi organisasi sebagai berikut (Kementerian BUMN, 2012): (1) Mewujudkan organisasi modern sesuai dengan tata kelola pemerintahan yang baik. (2) Meningkatkan daya saing BUMN di tingkat nasional, regional, dan internasional. (3) Meningkatkan kontribusi BUMN kepada ekonomi nasional.

Dengan spirit di atas, maka tidak ada jalan lain, Kementerian BUMN dan BUMN harus meningkatkan efisiensi, produktivitas dan efektivitasnya. Penerapan Teknologi Informasi menjadi suatu kewajiban, karena implementasi Teknologi Informasi mampu meningkatkan produktivitas, efisiensi dan efektivitas (Thatcher, 2011) Dengan tujuan tersebut, tidak berlebihan apabila Kementerian BUMN menerapkan salah satu Sasaran Strategis dalam kerangka Balance Scorecard pada Perspektif Pembelajaran dan Pertumbuhan (Learning and Growth) sebagai "Pengembangan sistem informasi yang modern" dengan cara meningkatkan"Persentase pencapaian Service Level Agreement Index (SLAI) sistem informasi" (Kementerian BUMN, 2012b).

\section{Perspektif BUMN}

Dalam Undang-Undang No 19 Tahun 2003 tentang BUMN, maka BUMN memiliki keleluasaan dalam pengelolaan manajemen (Republik Indonesia, 2003). Keleluasaan yang dimaksud sangat luas, seperti dicantumkan dalam Pasal 91: "Selain organ BUMN, pihak lain mana pun dilarang campur tangan dalam pengurusan BUMN" (Republik Indonesia, 2003). Dengan demikian BUMN memiliki otonomi yang luas dalam pengelolaan manajemennya. Termasuk dalam melakukan investasi Teknologi Informasi. Keleluasaan ini memberikan kesempatan bagi setiap BUMN untuk bisa memanfaatkan daya dukung Teknologi Informasi bagi kemajuan Perusahaan (key enabler). 
Diperkirakan telah ratusan milyar rupiah investasi yang ditanamkan pada Teknologi Informasi di seluruh BUMN. Dengan keleluasaan yang telah diberikan, maka konfigurasi investasi Teknologi Informasi menjadi sangat beragam. Keberagaman tersebut meliputi, nilai investasi, cakupan sistem, rentang waktu, dll. Kajian ini ditujukan untuk: (1) Badan Usaha Milik Negara di Indonesia khususnya Sektor Manufaktur. (2) Kajian hanya dilakukan untuk implementasi ERP, diluar investasi Hardware, Sistem Operasi, dan Sofware pendukung.

Riset ini dimaksudkan sebagai langkah awal untuk mengukur tingkat keberhasilan implementasi ERP di BUMN sektor Manufaktur. Riset ini ditujukan untuk menguji seberapa besar investasi yang telah ditanamkan dalam bidang Teknologi Informasi pada BUMN sektor manufaktur, dan sejauh mana investasi tersebut berguna bagi daya saing perusahaan maupun kontribusi bagi roda perubahan pada bisnis manufaktur di Indonesia. Lebih lanjut, dari riset ini akan dilakukan eksplorasi kinerja proyek implementasi Enterprise Resource Planning (ERP) secara signifikan dipengaruhi oleh pengelolaan, penentuan elemen kritis dan faktor kontekstual.

\section{Tinjauan Pustaka}

Investasi Teknologi Informasi (TI) pada organisasi terus meningkat sejak 1980-an, dan terus menerima perhatian dari para peneliti (Lin \& Shao, 2006). Meskipun sejumlah besar studi telah meneliti dampak dari investasi TI pada produktivitas organisasi untuk mengukur nilai bisnis dari IT, tetapi dari studi empiris sebagian besar hasil tidak sama (Ko, Clark, \& Ko, 2008). Evaluasi tingkat keberhasilan investasi dan implementasi Teknologi Informasi, terutama ERP dipicu oleh pandangan paradoksal Robert Solow tentang investasi dalam bidang Teknologi Informasi. Robert Solow mengungkapkan: "we see computers everywhere except in the productivity statistics.". Berbagai ilmuwan dunia secara khusus telah melakukan penelitian terhadap gejala paradoksal ini. Beberapa penelitian tentang tingkat keberhasilan implementasi ERP dilakukan oleh beberapa ilmuwan antara lain (Wickramasinghe \& Gunawardena, 2010).

Profesor Matin Saban dari Department of Business Administration Faculty of Economics and Administrative Sciences Bartın University, Turki secara khusus menyoroti efek Teknologi Informasi pada Akuntansi Manajerial di industri baja Turki. Saban telah meneliti perkembangan teknologi yang telah menyebabkan perubahan dalam akuntansi manajerial dan menguji bagaimana tingkat perubahan akuntansi manajerial, serta meneliti efek pada aplikasi akuntansi manajerial secara teoritis (Saban \& Efeoğlu, 2012). Selanjutnya, Anthony Rossa melakukan penelitian benchmarking produktivitas paradok dalam Teknologi Informasi pada bidang manufakturing dengan menggunakan model Data Envelopment Analysis (DEA). Model DEA tersebut digunakan Antony Rossa untuk menilai dampak TI terhadap produktifitas. (Rossa \& Ernstbergerb, 2006). Masalah kinerja yang menarik perhatian Anthony Rossa antara lain: menyelidiki hubungan antara alokasi sumber daya anggaran TI dan biaya, biaya tenaga kerja dianggap sebagai masukan (input) untuk produktivitas yang dicapai, dan produktifitas yang dicapai dianggap sebagai keluaran (output). Selain hubungan tersebut, Rossa juga melakukan benchmarking nilai relatif bisnis TI dibuat dalam sektor manufakturing. (Rossa \& Ernstbergerb, 2006)

Isu-isu tersebut diperiksa dengan menggunakan data kinerja yang dikumpulkan dari database Compustat $^{\mathrm{TM}}$ dan survei Information Week ${ }^{\mathrm{TM}}$ (IW) untuk eksekutif TI. Hasil penelitian menunjukkan bahwa, melalui skala efisiensi, perusahaan yang efisien dapat meningkatkan kinerja mereka dengan mengurangi investasi tertentu. Keseluruhan karakteristik perusahaan yang efisien disediakan sehingga perusahaan lain dapat meniru mereka dalam upaya untuk mencapai tingkat kinerja yang terbandingkan. (Rossa \& Ernstbergerb, 2006). Myung Ko dan Jan Guynes Clark melakukan penelitian dengan menggunakan metode Multivariate Adaptive Regression Splines (MARS) dalam menguji dampak investasi Teknologi Informasi (Ko, Clark, \& Ko, 2008). Metode ini telah mengatasi banyak kekurangan dari pendekatan tradisional, yang mengasumsikan hubungan linear antara variabel dependen dan independen dan normalitas distribusi kesalahan. MARS menawarkan teknik regresi 
yang fleksibel yang dapat mengungkap berbagai kemungkinan hubungan dalam data, termasuk hubungan nonlinear (jika ada), dan dapat memberikan wawasan tambahan untuk menyelidiki masalah yang kompleks, seperti dampak TI pada produktivitas.

\section{Keberhasilan Implementasi ERP}

Tingkat keberhasilan implementasi ERP dapat dipandang dari beberapa sudut pandang, antara lain (Wickramasinghe \& Gunawardena, 2010): (1) Accuracy. (2) Clarity. (3) Content of the system. (4) Flexibility. (5) Intended business performance improvement/achievement of predetermined corporate goals. (6) On time. (7) Reliability. (8) System acceptance and usage. (7) System stability. (8) Timeliness/ respons time. (9) User satisfaction. (10) Within budget.

\section{Elemen Kritis pada Keberhasilan Implemerntasi ERP}

Sementara itu keberhasilan implementasi ERP sangat tergantung pada bagaimana manajemen perusahaan memberikan perhatian pada Elemen Kritis (Wickramasinghe \& Gunawardena, 2010). Adapun elemen kritis yang perlu dipertimbangkan antara lain: (1) Appropriate business and IT legacy systems. (2) BPR and minimum customisation. (3) Business plan and vision. (4) Change management programme and culture. (5) Effective communication; Inter departmental corporation. (6) Managing user expectations. (7) Monitoring and evaluation of performance. (8) Project champion. (9) Project management. (10) Project team competence, compositionand teamwork. (11) Software development, testing and trouble shooting. (12) Top management support. (13) User involvement. (14) User training and education.

Dari uraian di atas, maka hipotesis dalam penelitian ini adalah:

Tabel 1 Daftar Hipotesis penelitian

\begin{tabular}{cl}
\hline Hipotesis & Deskripsi \\
\hline H1 & $\begin{array}{l}\text { Faktor pengelolaan proyek berpengaruh } \\
\text { signifikan terhadap tingkat keberhasilan } \\
\text { implementasi ERP. }\end{array}$ \\
& $\begin{array}{l}\text { Faktor penentuan urgensi elemen kritis } \\
\text { proyek berpengaruh signifikan terhadap } \\
\text { tingkat keberhasilan implementasi ERP. }\end{array}$ \\
H2 & $\begin{array}{l}\text { Faktor kontekstual proyek berpengaruh } \\
\text { signifikan terhadap tingkat keberhasilan } \\
\text { implementasi ERP. }\end{array}$ \\
\hline
\end{tabular}

\section{METODE}

\section{Kerangka Model}

Tingkat keberhasilan Implementasi ERP dipengaruhi oleh tiga hal, yaitu sebagaimana diagram di bawah menggambarkan keterkaitan antara Tingkat keberhasilan Implementasi ERP dan tiga faktor tersebut. 


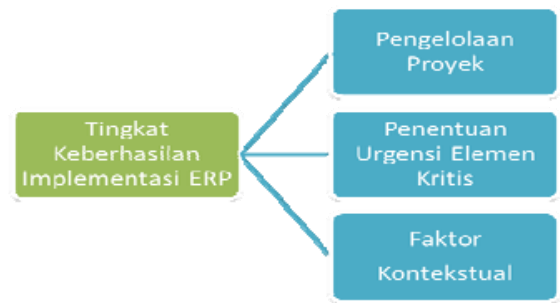

Gambar 1 Tingkat keberhasilan Implementasi ERP dengan 3 faktor.

\section{Pengelolaan Proyek}

Kinerja implementasi ERP dapat dilakukan melalui anggota Team Proyek dan tidak dilakukan melalui pengguna akhir (Wickramasinghe \& Gunawardena, 2010). Selanjutnya pencapaian beberapa tujuan yang telah ditentukan, meliputi parameter sebagai berikut (Wickramasinghe \& Gunawardena, 2010). Diagram dibawah menggambarkan keterkaitan antara pengelolaan proyek dan 9 parameter berikut:

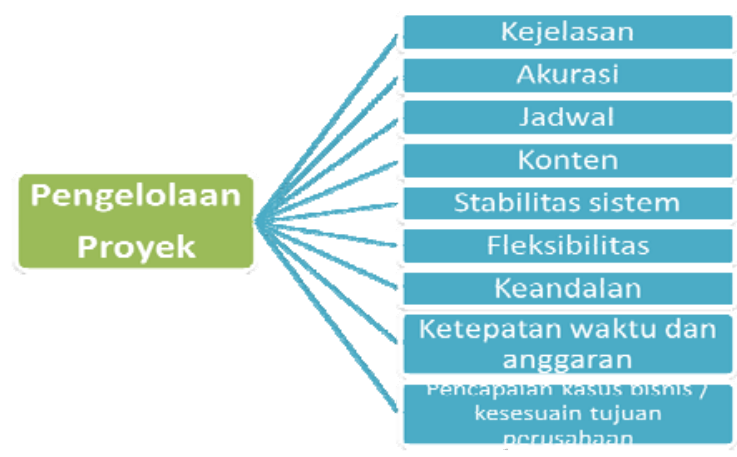

Gambar 2 Pengelolaan proyek dan 9 parameter

\section{Penentuan Urgensi Elemen Kritis}

Terjadi perbedaan tingkat kepentingan yang signifikan yang diberikan pada Elemen Kritis (CE) antara implementasi ERP yang sukses dan gagal, di mana pentingnya diberikan dalam tingkat urgensi dalam implementasi yang sukses. Aspek CE yang dikaji antara lain:

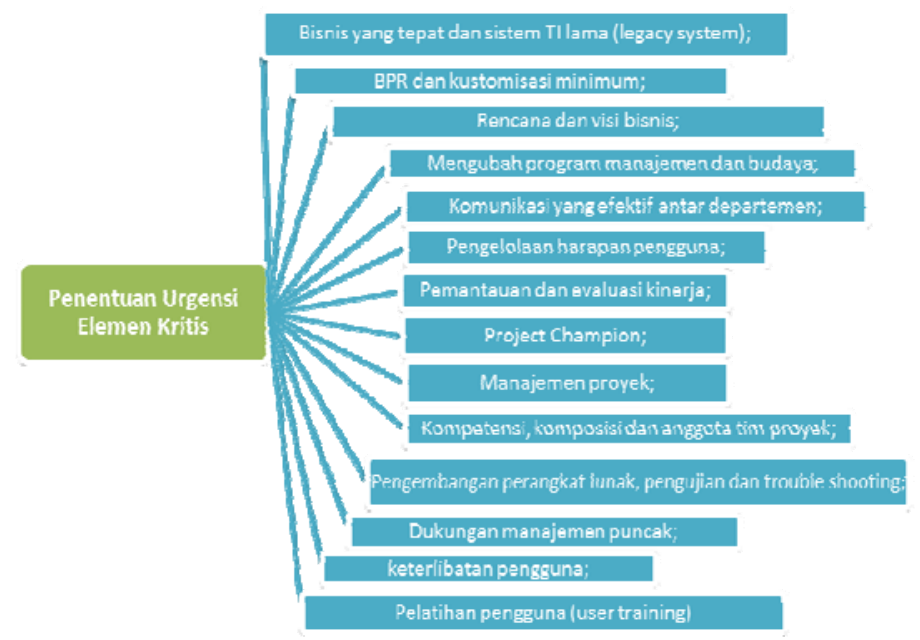

Gambar 3 Elemen Kritis proyek dan 14 parameter 
Vendor ERP menggunakan platform yang berbeda antara hardware, database, dan sistem operasi, paket ERP tertentu hanya kompatibel dengan database tertentu dan sistem operasi tertentu. Oleh karena itu, beberapa literatur ERP mengidentifikasi kebutuhan pengembangan perangkat lunak, pengujian dan pemecahan masalah sebagai bahan penting dalam implementasi ERP (Wickramasinghe \& Gunawardena, 2010).

Menerapkan sistem ERP melibatkan rekayasa ulang proses bisnis yang ada untuk memperbaiki standar proses bisnis mereka. Paket ERP menyediakan desain bisnis yang generik dan solusi perangkat lunak yang standar. Kelebihan atau kekurangan proses bisnis yang diinginkan tidak dapat sepenuhnya dapat dipenuhi, terutama ketika proses bisnis perusahaan yang unik. Oleh karena itu, rekayasa ulang proses bisnis dan kustomisasi minimum diidentifikasi sebagai faktor penting yang membantu keberhasilan. Pemantauan terus menerus dan evaluasi kinerja, juga diidentifikasi sebagai hal penting dalam implementasi ERP. Sementara itu banyak implementator menekankan pentingnya dukungan manajemen puncak sebagai bahan penting dalam implementasi ERP. Hal ini sebagai akibat dari kebiasaan implementasi ERP yang memicu perubahan besar dalam budaya organisasi dan praktek bisnis. Implementasi ERP memerlukan orang-orang penting di seluruh organisasi untuk menciptakan sebuah visi yang jelas dan menarik tentang bagaimana seharusnya sistem beroperasi untuk memuaskan pelanggan, memberdayakan karyawan, dan memfasilitasi pemasok.

Project Champion diidentifikasi dan dikaitkan dengan keberhasilan inovasi teknologi. Karena Project Champion dapat bertindak sebagai kepemimpinan transformasional. Keberhasilan implementasi ERP memerlukan manajemen proyek yang sangat baik. Hal ini termasuk definisi yang jelas tentang tujuan, pengembangan dan rencana sumber daya dan evaluasi kemajuan proyek. Selain masalah tersebut, faktor-faktor dibawah ini juga penting dalam memberikan kontribusi keberhasilan implementasi ERP. Faktor tersebut antara lain: kerja sama tim, komposisi tim, komunikasi yang efektif, sistem yang sesuai bisnis dengan sistem lama, kerjasama dan komunikasi antar departemen, manajemen harapan.

\section{Faktor Kontekstual}

Hubungan antara faktor-faktor kontekstual dari suatu organisasi dan dampaknya terhadap berbagai operasi telah dipelajari untuk waktu yang lama (Wickramasinghe \& Gunawardena, 2010). Dampak ukuran organisasi pada adopsi, implementasi dan penggunaan teknologi informasi telah mendapat perhatian dalam literatur akademik (Wickramasinghe and Gunawardena, 2010). Faktor tersebut adalah sebagaimana diagram dibawah ini menggambarkan hal tersebut:

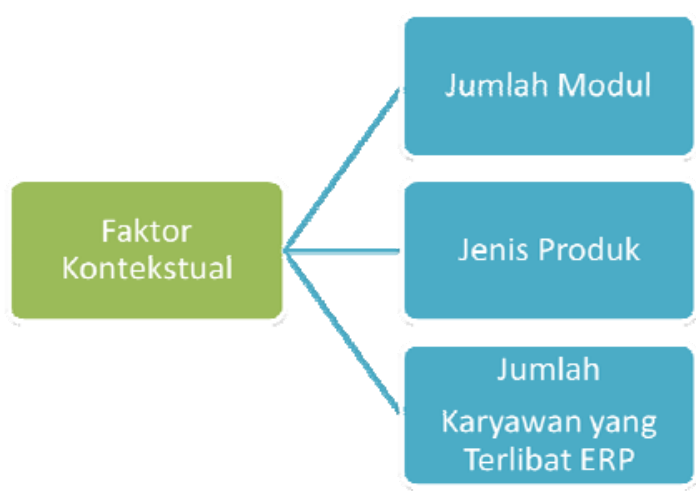

Gambar 4 Kontekstual proyek dan 3 parameter 


\section{Rancangan Penelitian}

Penelitian ini termasuk dalam jenis penelitian eksplanasi, yang bersifat noneksperimen dan bertujuan menjelaskan pengaruh Manajemen Proyek, Penentuan Urgensi Elemen Kritis dan Faktor Kontektual terhadap terhadap tingkat keberhasilan Implementasi ERP. Populasi diambil dari anggota Perusahaan Manufaktur yang terdiri dari PT. Karakatau Steel dan PT. KHI Pipe Industries.

Variabel-variabel yang dipergunakan dalam penelitian ini terdiri dari Variabel terikat yaitu Keberhasilan Implementasi ERP dinotasikan sebagai $\mathrm{Y}$ dan Variabel bebas yaitu Pengelolaan/Manajemen Proyek, dinotasikan sebagai X1, Penentuan Urgensi Elemen Kritis, dinotasikan sebagai X2 dan Faktor Kontekstual, dinotasikan sebagai X3.

\section{Instrumen Penelitian Dan Data Analisis}

Instrumen yang digunakan untuk mengukur Keberhasilan Implementasi ERP, Urgensi Elemen Kritis, Pengelolaan Manajemen Proyek dan Faktor Kontektual adalah kuesioner yang didasarkan atas sistem penilaian skala Likert. Metode ini merupakan penskalaan pernyataan sikap yang menggunakan distribusi respon sebagai dasar penentuan nilai skalanya. Jumlah alternatif respon yang ada dalam skala Likert ada lima jenis (sangat setuju, setuju, ragu-ragu, tidak setuju, sangat setuju). Untuk mengurangi kecenderungan responden menjawab pilihan ragu-ragu, karena objek penilaian yang cukup sensitif, maka pada penelitian ini pilihan jawaban ragu-ragu sengaja tidak diberikan sebagai alternatif jawaban bagi responden.

\section{Pengukuran Keberhasilan Implementasi ERP}

Pengukuran Keberhasilan Implementasi ERP adalah dengan menggunakan kuesioner yang diberikan kepada karyawan yang ditunjuk oleh LO. Untuk mengungkap Keberhasilan Implementasi ERP yang mempunyai sistem penilaian skala Likert yang dimodifikasi menjadi empat alternatif jawaban. Penyusunan kuesioner ini juga dikelompokkan dalam item favorabel dan item-item unfavorabel. Penyusunan kuesioner Keberhasilan Implementasi ERP dilakukan dengan menggunakan penilaian skala Likert dan bukan kuesioner yang meminta responden untuk memilih alternatif dua jawaban dikarenakan permasalahan yang diteliti cukup sensitif. Pemakaian skala Likert dalam hal ini dilakukan dengan tujuan meminimalkan terjadinya kecemasan responden dalam menjawab.

\section{Pengukuran Pengelolaan Manajemen Proyek}

Pengukuran Pengelolaan Manajemen Proyek dilakukan dengan memfokuskan faktor-faktor yang telah disebutkan diatas. Pengukuran dilakukan dengan cara meminta responden memilih pernyataan yang sesuai dengan apa yang mereka alami di perusahaan, dan dipergunakan sistem penilaian berdasarkan skala Likert.

\section{Urgensi Elemen Kritis}

Adalah dengan menggunakan kuesioner tentang CE. Untuk mengungkap Urgensi Elemen Kritis, digunakan sistem penilaian dengan menggunakan skala Likert yang dimodifikasi menjadi 4 alternatif jawaban.

\section{Pengukuran Faktor Kontekstual}

Pengukuran Pengelolaan Manajemen Proyek dan Faktor Kontekstual dilakukan dengan memfokuskan faktor-faktor yang telah disebutkan diatas. Pengukuran dilakukan dengan cara meminta responden memilih pernyataan yang sesuai dengan apa yang mereka alami di perusahaan, dan dipergunakan sistem penilaian berdasarkan skala Likert. 


\section{Analisis Data}

Untuk meperoleh gambaran tentang karakterisitik, maka dilakukan deskripsi data untuk variabel demografi. Untuk mengetahui pola hubungan antara Urgensi Elemen Kritis dan Pengeloalan Manajemen Proyek dan Faktor Kontektual dengan Keberhasilan Implementasi ERP menggunakan analisis regresi linear berganda.

Model dari Analisis Regresi Linear berganda adalah sebagai berikut:

$$
\mathbf{Y}=\mathbf{a}_{0}+\mathbf{a}_{1} \mathbf{X}_{1}+\mathbf{a}_{2} \mathbf{X}_{2}+\mathbf{a}_{3} \mathbf{X}_{3}
$$

dengan:

- Y adalah variable terikat

- a adalah konstanta

- X adalah variable bebas

Tahap-tahap dalam analisis data adalah sebagai berikut: (1) Uji validitas dan reliabilitas dari kuesioner untuk mengetahui sejauh mana kuesioner ini konsisten terhadap variabel-variabelnya. (2) Tahap pengolahan data dan analisis statistik deskriptif untuk mengetahui karakteristik dari responden. (3) Tahap pengolahan data dengan analisis regresi logistik, untuk mencari pengaruh antara variabel Urgensi Elemen Kritis dan Pengelolaan Manajemen Proyek dan Faktor Kontektual terhadap variabel Keberhasilan Implementasi ERP.

\section{HASIL DAN PEMBAHASAN}

\section{Gambaran Umum Objek Penelitian}

\section{PT Krakatau Steel (Persero) Tbk}

PT Krakatau Steel (Persero) Tbk. (PTKS) adalah perusahaan baja terbesar yang dianggap mewakili BUMN manufaktur di Indonesia. BUMN yang berlokasi di Cilegon, Banten ini berdiri pada tanggal 31 Agustus 1970. Produk yang dihasilkan adalah baja lembaran panas, baja lembaran dingin, dan baja batang kawat. Hasil produk PTKS pada umumnya merupakan bahan baku untuk industri lanjutannya. Perkembangan Krakatau Steel sebagai perusahaan yang bergerak di bidang industri baja berlangsung cukup maju. Dalam kurun waktu kurang dari sepuluh tahun, Perseroan sudah menambah berbagai fasilitas produksi seperti Pabrik Besi Spons, Pabrik Billet Baja, Pabrik Batang Kawat, serta fasilitas infrastruktur berupa pusat pembangkit listrik, Pusat Penjernihan Air, pelabuhan khusus Cigading dan sistem telekomunikasi.

Dengan perkembangan ini, PT Krakatau Steel (Persero) menjadi satu-satunya perusahaan baja yang terpadu di Indonesia. Perseroan terus mengembangkan produksi berbagai jenis baja untuk bermacam keperluan, seperti baja lembaran panas, baja lembaran dingin dan batang kawat. Saat ini, Krakatau Steel memiliki kapasitas produksi baja kasar sebesar 2,45 juta ton per tahun untuk mendukung produksi baja tersebut. Dan dengan sepuluh anak perusahaan Krakatau Steel sanggup mendiversifiasi usahanya pada usaha-usaha penunjang yang menghasilkan berbagai produk baja bernilai tambah tinggi (seperti pipa spiral, pipa ERW, baja tulangan, baja profil), meyediakan industri utilitas (air bersih, tenaga listrik), industri infrastruktur (pelabuhan, kawasan industri), industri jasa teknik (konstruksi, rekayasa), teknologi informasi, serta menyediakan layanan kesehatan (rumah sakit). Produk- produk baja Krakatau Steel ini tak hanya ditujukan untuk memenuhi kebutuhan baja nasional, tetapi juga dipasarkan secara internasional. 
Kemampuan teknis Krakatau Steel yang tinggi sudah diakui menurut standar internasional sejak dahulu kala. Bahkan pada 1973 Perseroan sudah memperoleh Sertifikat ASTM A252 dan AWWA C200, serta pada 1977 memperoleh Sertifiat API 5L untuk produksi pipa spiral. Sertifikat ISO 9001 diperoleh PT Krakatau Steel (Persero) pada 1993 dan telah ditingkatkan menjadi ISO 9001:2000 pada 2003. Sementara itu, SGS internasional memberikan Sertifiat ISO 14001 pada 1997 atas komitmen Perseroan pada kesadaran lingkungan dan keselamatan kerja. Pada 10 November 2010, di tengah kondisi pasar yang masih bergejolak, PT Krakatau Steel (Persero) berhasil menjadi perusahaan terbuka dengan melaksanakan penawaran umum perdana (IPO) dan mencatatkan sahamnya di Bursa Efek Indonesia. Pada tahun 2011, PT Krakatau Steel (Persero) Tbk. membukukan pendapatan bersih sebesar Rp17,9 triliun dan laba bersih Rp 1,02 triliun. Pada tahun 2011, Perseroan dan anak perusahaan dengan aset senilai Rp21,5 triliun memiliki 8.023 orang karyawan. (PT. Krakatau Steel (Persero) Tbk., 2011)

\section{PT. KHI Pipe Industries}

PT KHI Pipe Industries (KHI) adalah pembuatan baja pipa sejak tahun 1972 sebagai anak perusahaan dari PT Krakatau Steel. Perusahaan ini berada pada area kawasan Krakatau Industrial Estate Cilegon Banten, Indonesia.Lebih dari 40 tahun pembuatan pipa, KHI dengan sertifikasi API 5L telah mengumpulkan pengalaman yang luas pada proyek domestik dan internasional. Hal ini telah mengukuhkan KHI dalam industri pipa baja.

\section{Responden}

Responden diberikan kepada Manager aktif di PTKS dan KHI, dan kepada naggota Team Implementasi ERP PTKS dan PT. KHI. Kuisoner diberikan dalam pola tertulis (paper) dan on-line.

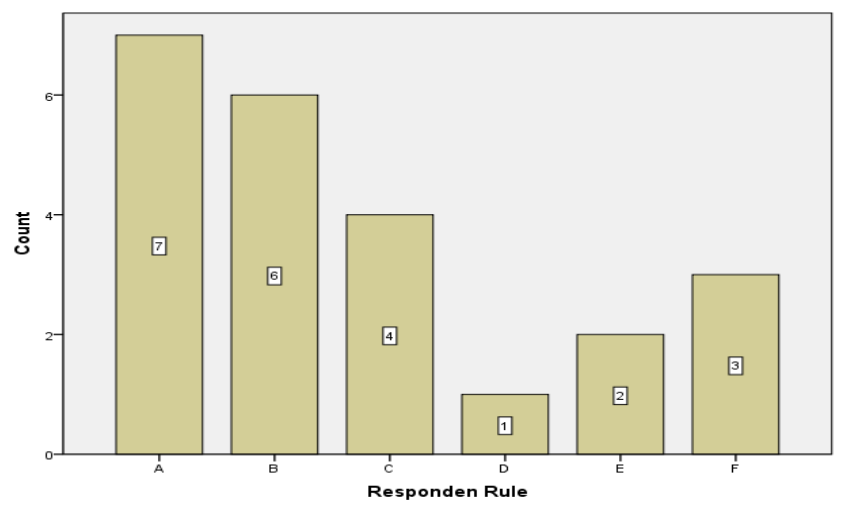

Gambar 5 Demografi Responden

Catatan:

A. Manajemen secara Umum

B. Keuangan dan Akuntansi

C. Operasional/Produksi/Perawatan

D. Perencanaan Produksi/ Penjaminan Kualitas/ Manajemen Stratejik

E. Penjualan dan Manajemen pemasaran

F. Lainnya 


\section{Berdasarkan Asal Responden}

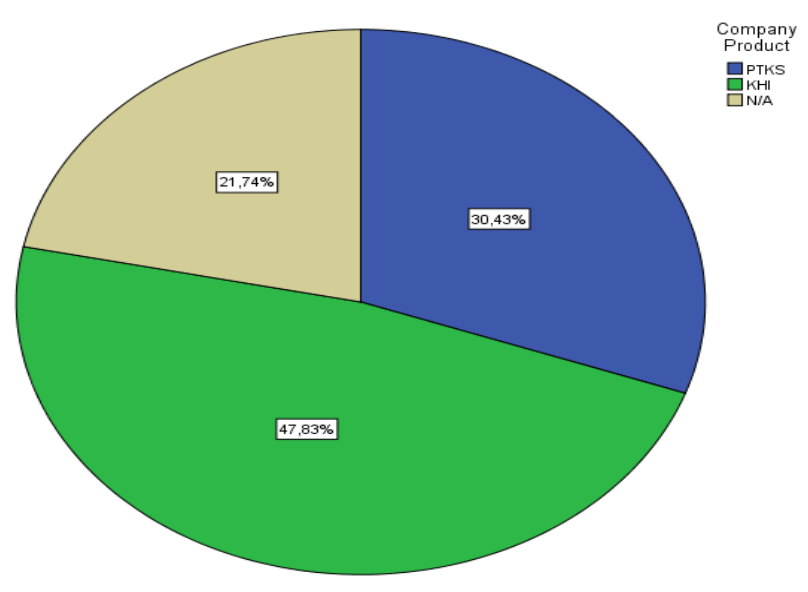

Gambar 6 Asal Responden

\section{Catatan:}

1. PTKS: PT. Krakatau Steel (Persero) Tbk

2. KHI: PT. KHI Pipe Industries

3. N/A: Tidak mengisi data

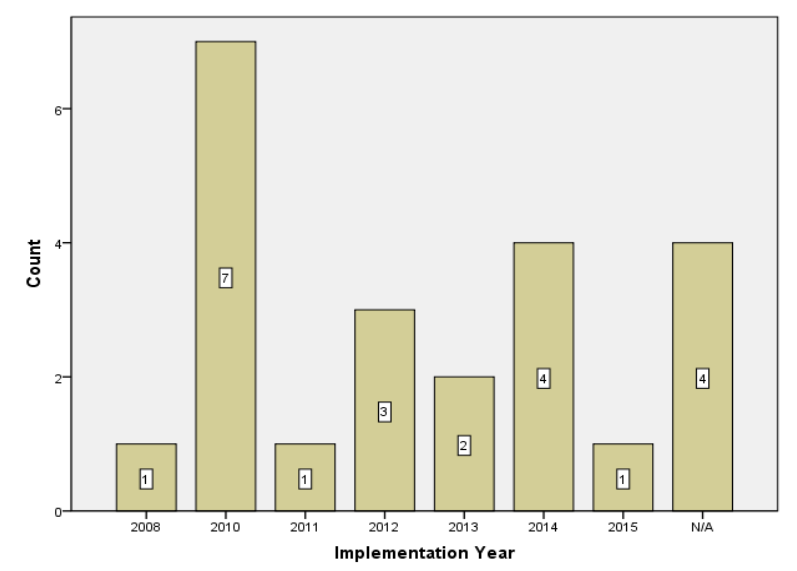

Gambar 7 Tahun Kepesertaan Responden dalam Implementasi ERP

\section{Pengujian hipotesis}

Pengujian hipotesis menggunakan metoda resampling bootstrap. Dari prosedur bootstrapping ini akan menghasilkan nilai T-Statistik dari masing-masing variabel eksogen (variabel independen) terhadap variabel endogen (variabel dependen).

Tabel 2 Hasil prosedur bootstrapping

\begin{tabular}{ccc}
\hline Inner Model Path Coefficient & Standard Error & T-Statistic \\
\hline H1 & 0,126 & 0,985 \\
H2 & 0,072 & 8,828 \\
H3 & 0,120 & 2,731 \\
\hline
\end{tabular}


Dari hasil prosedur bootstrapping di atas, maka dapat dilakukan pengujian hipotesis mengacu kepada Rule of Thumb dengan ketentuan sebagai berikut:

Signifikansi (two-tailed) level 10\% sebesar 1,65

Signifikansi (two-tailed) level 5\% sebesar 1,96

Signifikansi (two-tailed) level 1\% sebesar 2,58

Tabel 3 Pengujian hipotesis

\begin{tabular}{cccl}
\hline Hipotesis & $\mathbf{R}^{2}$ & T-Value & Kesimpulan \\
\hline H1 & & $2,985^{* *}$ & $\begin{array}{l}\text { Hipotesis } \\
\text { diterima }\end{array}$ \\
H2 & 0,753 & $8,828^{* *}$ & $\begin{array}{l}\text { Hipotesis } \\
\text { diterima }\end{array}$ \\
H3 & & $6,731^{* *}$ & $\begin{array}{l}\text { Hipotesis } \\
\text { diterima }\end{array}$ \\
\hline
\end{tabular}

*Signifikansi at $P<0,05, * *$ Signifikansi at $P<0,01$

Dengan demikian, kesimpulan yang dapat ditarik dari tabel diatas adalah:

H1 : Faktor pengelolaan proyek berpengaruh signifikan terhadap tingkat keberhasilan implementasi ERP

H2 : Faktor penentuan urgensi elemen kritis berpengaruh signifikan terhadap tingkat keberhasilan implementasi ERP

H3 : Faktor kontekstual berpengaruh signifikan terhadap tingkat keberhasilan implementasi ERP.

\section{SIMPULAN}

Faktor pengelolaan proyek yang merupakan faktor penting yang berpengaruh signifikan di BUMN Manufaktur untuk Keberhasilan Implementasi ERP. Perlu ditingkatkan kepada BUMN Manufaktur, pemahaman yang mendalam terhadap benefit (relative advantage), keamanan (uncertainty), kesesuaian (compatibility), kesulitan (complexity), uji coba (triability), dan obervasi (observability), yang menjadi indikator dari faktor teknologi. Walau demikian, ditemukan bahwa kesesuaian dan observasi merupakan indikator kuat di dalam ini. BUMN Manufaktur menyadari betul bahwa suatu inovasi teknologi seperti layanan Keberhasilan Implementasi ERP sangat perlu dicermati tingkat kesulitannya, serta melakukan observasi dari pengalaman oleh organisasi lain.

Layanan Keberhasilan Implementasi ERP sangat berpotensi untuk diadopsi oleh BUMN Manufaktur ditinjau dari penentuan urgensi elemen kritis proyek. Dari faktor penentuan urgensi elemen kritis proyek, yang paling berperan bagi BUMN Manufaktur untuk Keberhasilan Implementasi ERP adalah dengan adanya dukungan dari top management, tingkat inovasi organisasi, dan bekal skill yang dimiliki BUMN Manufaktur saat ini. Dalam penelitian ini ditemukan faktor yang paling kuat mempengaruhi BUMN Manufaktur untuk Keberhasilan Implementasi ERP adalah faktor penentuan urgensi elemen kritis proyek.

Selain faktor penentuan urgensi elemen kritis proyek, faktor kontekstual proyek menempati urutan kedua yang menjadi faktor berpengaruh bagi BUMN Manufaktur untuk Keberhasilan Implementasi ERP. Kompetisi, jenis industri, dan kebijakan pemerintah, adalah indikator yang kuat dalam faktor ini. Faktor pengelolaan proyek, penentuan urgensi elemen kritis proyek, dan kontekstual proyek menuju kepada satu variabel yang sama yaitu Keberhasilan Implementasi ERP. Setelah 
dilakukan beberapa pengujian, maka dapat dinyatakan bahwa hasil ketiga hipotesis yang ada bersifat konsisten. Ketiga faktor bebas yang menuju ke satu variabel bebas yang sama, tidak saling mempengaruhi satu sama lainnya.

Model yang disajikan di sini diharapkan dapat digunakan sebagai alat untuk mengoptimalkan pelaksanaan ERP, baik sebelum dan selama proses pelaksanaan. Selain itu, kami berharap bahwa penelitian di masa datang secara empiris mengkaji aspek perilaku individu dan kolektif dampak pada sukses implementasi ERP. Secara keseluruhan, model ini dapat dimanfaatkan untuk membantu mengintegrasikan bagian ke dalam model mereka sendiri terkait sukses implementasi ERP. Penulis artikel ini mendorong pengembangan lebih lanjut melalui pekerjaan empiris yang menggunakan model dalam penelitian yang terbaru atau diperbaharui.

\section{DAFTAR PUSTAKA}

Departemen Keuangan. (2010, November). APBN 2011 Sebuah Momentum Menuju Akselerasi Ekonomi. Media Keuangan, 39.

Kementerian BUMN . (2012a). Kinerja BUMN Tahun 2011-2012. Jakarta: Kementerian BUMN.

Kementerian BUMN. (2012b). Rencana Strategis Kementerian BUMN Tahun 2012-2014. Jakarta: Kementerian BUMN.

Ko, M., Clark, J. G., \& Ko, D. (2008). Revisiting the impact of information technology investments on Productivity: an empirical investigation Using Multivariate adaptive regression splines (Mars). (M. Khosrow-Pour, Penyunt.) Information Resources Management Journal, 21(3).

Republik Indonesia. (2003). Undang Undang No 19 Tahun 2003 tentang Badan Usaha Milik Negara. Lembaran Negara Republik Indonesia Tahun 2003 Nomor 70. Sekretariat Negara. Jakarta.

Rossa, A., \& Ernstbergerb, K. (2006). Benchmarking the IT productivity paradox: Recent evidence from the manufacturing sector. Mathematical and Computer Modelling, 44: 3-42.

Saban, A. P., \& Efeoğlu, Z. (2012). An Examination of the Effects of Information Technology on Managerial Accounting in the Turkish Iron and Steel Industry .03(12).

Shao, B. B. M., Winston, T. L. (2002). Technical Efficiency Analysis of Information Technology Investments: A Two-stage Empirical Investigation. Information and Management, 39: 391401

Thatcher, M. E. (2011). The Impact of Technology Investment on a Firm's Production Efficiency, Product Quality, and Productivity. Journal of Management Information Systems, 18, 17.

Wickramasinghe, V., \& Gunawardena, V. (2010). Critical elements that discriminate between successful and unsuccessful ERP implementations in Sri Lanka. Journal of Enterprise Information Management, 23, 466.

World Economic Forum. (2013). The Global Information Technology Report 2013. 358 